\title{
Magma mixing in CRetaceous Kamafugites, Goiás Alkaline Province, Brazil.
}

\author{
Tereza Cristina Junqueira Brod ${ }^{1,2}$, José Carlos Gaspar ${ }^{1,2}$, José Affonso Brod ${ }^{1,2}$ and Elisa Soares \\ Rocha Barbosa ${ }^{1,2}$ \\ ${ }^{1}$ Universidade de Brasília,Brazil. ${ }^{2}$ CNPq, Brazil
}

\section{INTRODUCTION}

In central Brazil, cretaceous volcanic kamafugites of the Goiás Alkaline Province (GAP) intrude the precambrian basement, phanerozoic sediments of the Paraná Basin and basalts of the Serra Geral Formation, in the northeast margin of the Paraná Basin. The GAP is characterised by the dominance of plutonic bodies in the north, lavas in the south, and diatremes or subvolcanic bodies in the central portion. A series of magma mixing features were identified in these kamafugites, and are the main subject of this work.

\section{GEOLOGICAL SETTING}

Coherent volcanic rocks crop out both in Central and Southern portions of the province. In the central GAP, they occur as lava flows, dykes, plugs or as metric pockets inside diatremes, and also as fragments within diatreme breccias of the Águas Emendadas region (Figure 1). In the Southern GAP they comprise extensive lava flows, alternated with autobreccias and pyroclastic deposits of the Santo Antônio da Barra region.

The main petrographic types in the Santo Antônio da Barra volcanics include melaleucitite (ugandite), kamafugite (mainly mafurite), and subordinate carbonatitic pyroclastics. Associated late dykes and plugs comprise fourchites, melamonchiquites, phonolites and trachytes Gaspar and Danni, 1981). Hasui et al. (1971) obtained a K-Ar age of $85 \mathrm{Ma}$ for the volcanic rocks. The volcanic strata are intercalated and overlain by coeval epiclastic sediments of the Verdinho Formation, and both are covered by sedimentary rocks of the Bauru Group (Gaspar and Danni, 1981). The presently preserved volume of the kamafugitic lavas is $23 \mathrm{~km}^{3}$ (Junqueira-Brod et al. 2002).

The Águas Emendadas Region, in Central GAP, is located between the towns of Amorinópolis and Montividiu. It comprises dykes, plugs, volcanic vents and pyroclastic deposits, usually emplaced in paleozoic sandstones of the Aquidauana Formation and covered by the Bauru Group. The main petrographic types among the coherent rocks are kamafugite, melaleucitite, leucitite, basanite and tephrite (Junqueira-Brod 1998). These rocks were considered an extension of the alkaline volcanics of Santo Antônio da Barra (Danni et al., 1990).

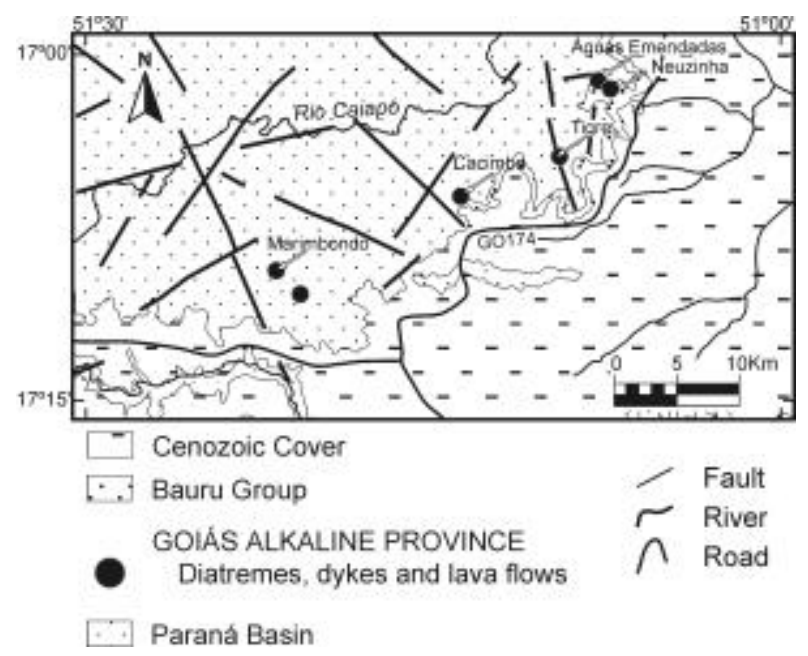

Figure 1: Map of Águas Emendadas Region (Central GAP), modified from Lacerda Filho et al. (2000)

Lava flows of melaleucitite and kamafugite usually cover diatreme structures infilled by breccias and subordinate tuffs. Dykes and plugs of kamafugite and melaleucitite cut the diatremes as well as the country rock (Junqueira-Brod 1998).

Diamonds are found in the alluvial deposits of the Caiapó river, nearby. The origin of these stones is controversial. Tompkins (1987) argues that the lithosphere in the region is under $150 \mathrm{~km}$ thick and considers the primary diamond source to be precambrian. On the other hand, Danni et al. (1990) suggest that the source is related to the cretaceous GAP magmatism.

\section{PETROGRAPHY}

Considering only the ultramafic volcanic and subvolcanic coherent rocks from the Águas Emendadas region, samples from dykes, plugs, lava flows and juvenile fragment in diatreme breccias share the same 
range of petrographic features. They vary from aphanitic to strongly porphyritic, where the main phenocryst phases are diopside, olivine and subordinate leucite and phlogopite, set in a groundmass composed essentially of olivine, diopside, kalsilite, leucite, phlogopite, perovskite, melilite, apatite and titanomagnetite.

All ultramafic coherent rocks from the Águas Emendadas region have strong chemical affinity with kamafugites (Junqueira-Brod, 1998). Kalsilite-bearing rocks are referred to here simply as kamafugites since they do not exactly match any of the subdivisions proposed by Woolley et al. (1996). Kalsilite-lacking rocks, consistently richer in leucite, are classified as melaleucitite (in the sense of Woolley et al. 1996), corresponding to the former ugandite (in the sense of Sahama 1974). Compared with the melaleucitites, kamafugites are much poorer in phenocrysts but richer in vesicles. These may be of variable size, usually infilled by carbonate and zeolites and range from 0 to about 70 volume $\%$.

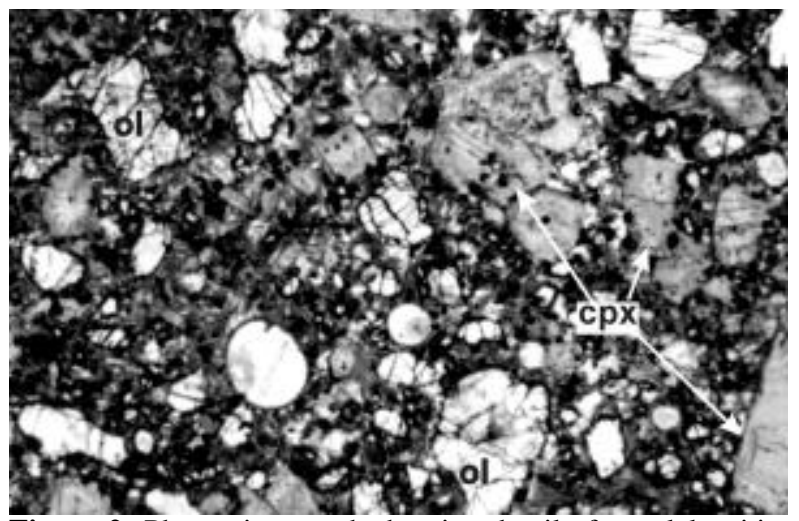

Figure 2: Photomicrograph showing detail of a melaleucitite cognate fragment with abundant clinopyroxene (px) and olivine (ol) with corroded margins and zoning. Planepolarized light. Field of view is $1 \times 0.75 \mathrm{~mm}$. Águas Emendadas complex.

Two generations of olivine phenocrysts are recognizable. One is euhedral to subhedral, usually less than $3 \mathrm{~mm}$ in size. The second is normally anhedral and up to $1 \mathrm{~cm}$ in diameter, showing resorption features. Groundmass olivine is usually euhedral. The olivine grains are often partially or totally altered to serpentine and/or to a mixture of clay minerals and carbonate.

The pyroxene is normally fresh and diopsidic in composition. In thin section it can be strongly coloured from light brown to green. It occurs both as phenocrysts (up to $6 \mathrm{~mm}$ ) and as the main constituent of the groundmass. As a rule, the phenocrysts are euhedral, but some may show evidence of instability with the magma (Figure 2). Groundmass pyroxene occurs as euhedral microcrysts.
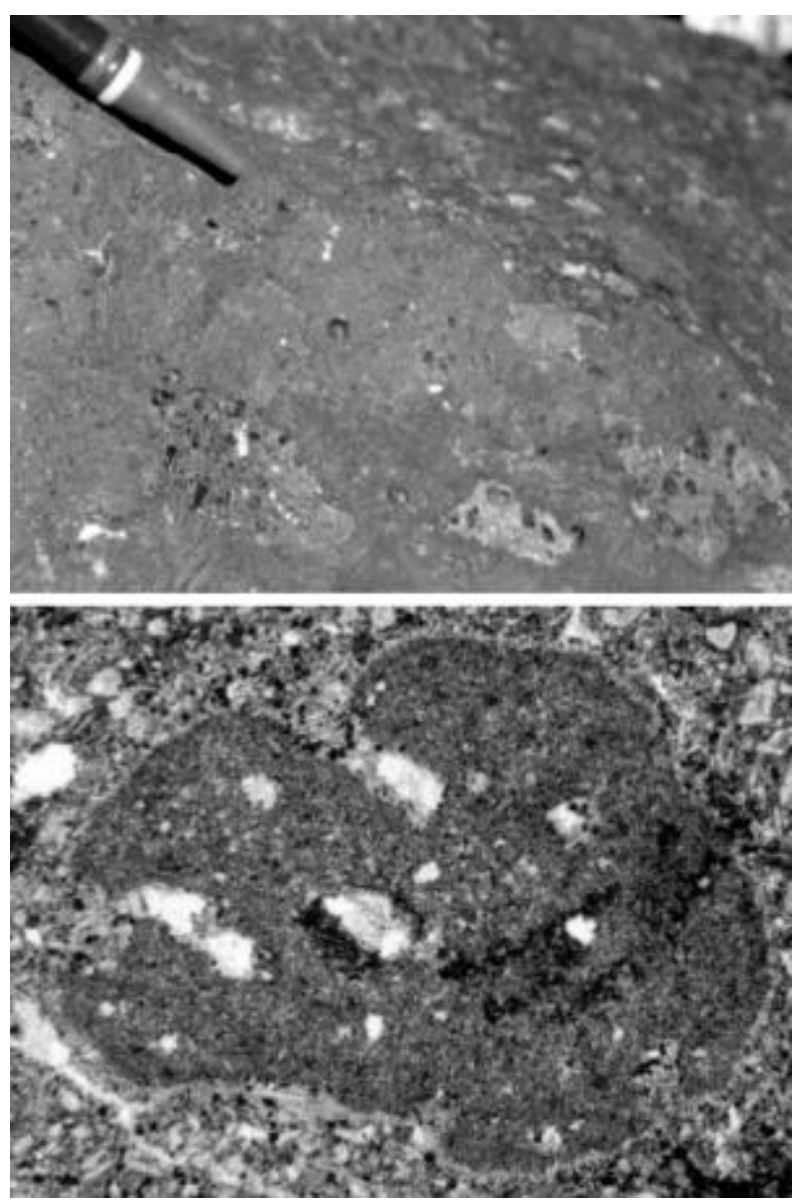

Figure 3 : Top - Abundant amoeboid inclusions in an outcrop of kamafugite lava. Bottom - Photomicrograph showing detail of an amoeboid inclusion of fine-grained kamafugite in a slightly coarser-grained kamafugite dyke. Plane-polarized light. Field of view is $2 \times 1.5 \mathrm{~mm}$. Águas Emendadas complex.

Leucite pseudomorphs forming anhedral to rounded, "cloudy", masses are an important groudmass constituent, next in abundance only to pyroxene and olivine. Phlogopite occurs both as phenocrysts and as a late-stage component of the groundmass. The phenocrysts are often partially or totally transformed into a microcrystalline mixture of Fe-Ti oxides, pyroxene, nepheline, and olivine. Euhedral perovskite is an important accessory mineral in most samples, occurring as microphenocrysts or small groundmass crystals. Fe-Ti oxides are very common, as euhedral microcrysts in the groundmass or inclusions in pyroxene and phlogopite phenocrysts. 
Small amounts of kalsilite are present, mainly as a late phase in the kamafugite groundmass. However this mineral is seldom entirely preserved, being transformed into potassium-rich nepheline.

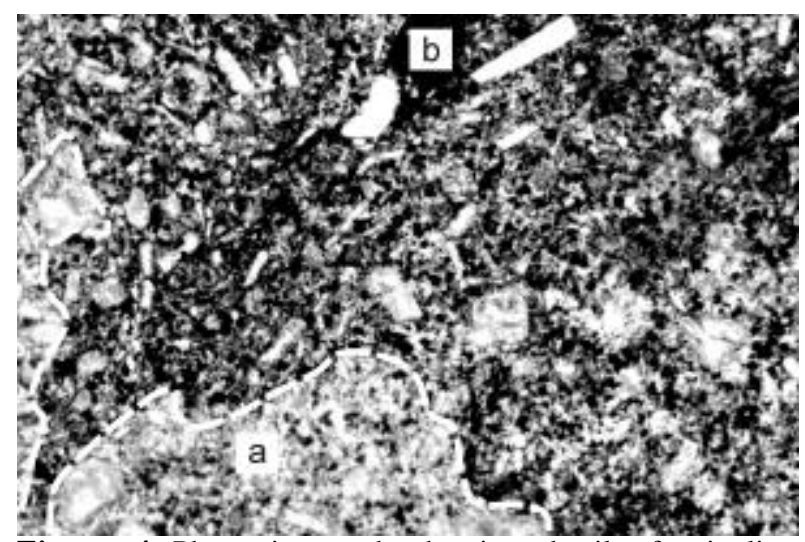

Figure 4 Photomicrograph showing detail of mingling patches in a kamafugite dyke. The mineralogy of host rock (a) and patch (b) is very similar, comprising microphenocrysts of clinopyroxene, olivine, perovskite and Ti magnetite in a glassrich groundmass. Plane-polarized light. Field of view is 2x1.5mm. Águas Emendadas complex.

A striking feature of the Águas Emendadas region kamafugites is the regular presence, both in outcrop (Figure 3, top) and in thin sections (Figure 3, bottom), of dark amoeboid inclusions. These vary in size from a few millimetres to centimetres, and have the same mineralogy as the host rock (Figure 4) but a finer grain size and higher modal abundance of pyroxene, olivine and perovskite microphenocrysts. Although ameboid shapes are the most common, elongate inclusions, patches or even stripes are also found, especially in juvenile fragments within diatreme breccias (Figure 5) or in lavas and dykes with significant flow orientation and banding. The inclusions provide compelling textural evidence for magma mixing events during the formation of both the coherent and pyroclastic kamafugites.

Cognate fragments are common in lavas and dykes, ranging in size from millimetres to a few centimetres. They are normally much richer in phenocrysts than the enclosing lava and show different degrees of crystallinity. Xenoliths of cumulate alkaline rocks such as pyroxenites, dunites and peridotites are also present. Some of the latter have strained textures, which may suggest a mantle origin.

\section{GEOCHEMISTRY}

The diagram of $\mathrm{Ni}$ versus Lu (Figure 6) shows that some samples from the Águas Emendadas region conform well to an exponential regression line, suggesting that they are related to each other through crystal fractionation. A number of other samples, however, especially those showing conspicuous petrographic evidence for magma mixing, fall reasonably well along a linear regression line. This is consistent with their origin by various degrees of mixing between a more primitive and a more evolved magma.

On the other hand, the primitive end-member forecast by the Ni-Lu relationships falls outside the range of analysed samples, suggesting that all studied rocks are, to a higher or lesser degree, products of differentiation from a more primitive composition. Representatives of such parental magmas either were not found or they did not reach the crustal level were the diatremes were formed.

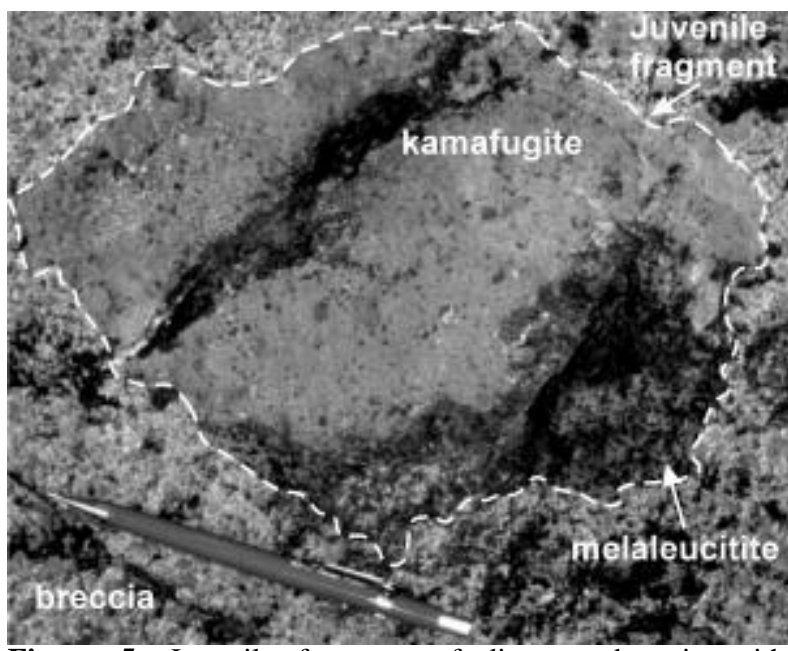

Figure 5: Juvenile fragment of diatreme breccia with preserved mixture of melaleucitite and kamafugite. Águas Emendadas complex.

Despite the absence of a truly primitive composition, most of the available geochemical evidence for the alkaline rocks the Águas Emendadas region, such as remarkably constant paired-element ratios $(\mathrm{Nb} / \mathrm{Ta}$, $\mathrm{Zr} / \mathrm{Hf}, \mathrm{Y} / \mathrm{Ho}$ ) and REE patterns suggest that kamafugites, melaleucitites and leucitites had a common or very similar mantle source (Junqueira-Brod 1998). 


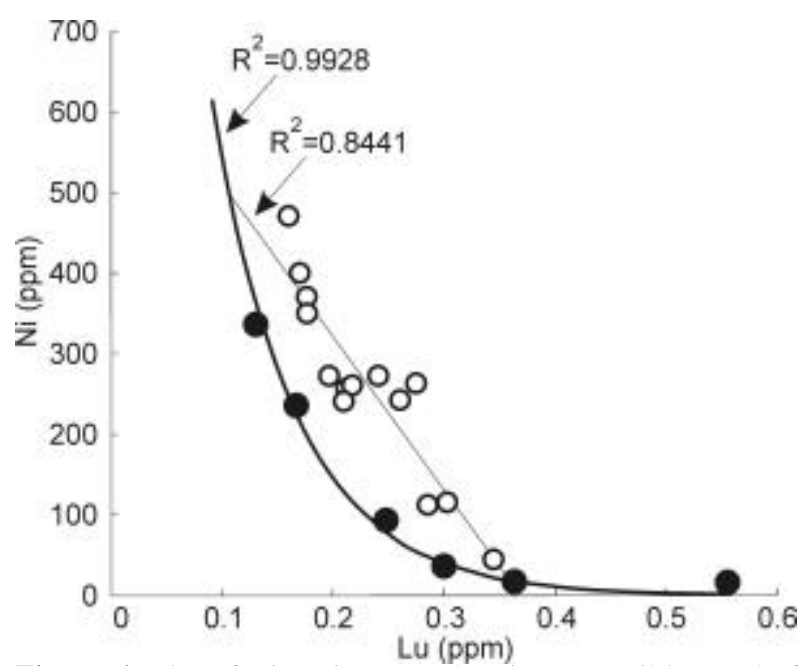

Figure 6: Plot of $\mathrm{Ni}$ against $\mathrm{Lu}$, showing a possible trend of crystal fractionation (full circles), and possible trend of magma mixing (open circles), for Águas Emendadas region rocks (central GAP).

\section{DISCUSSION}

The presence of pyroxene and olivine phenocrysts showing evidence of resorption by the magma and the abundance of "amoeboid" inclusions in samples from the Águas Emendadas region provide strong evidence for the involvement of magma mixing processes in the genesis of these rocks.

Cognate fragments are interpreted as having originated in the magma chamber and later remobilised by the ascending magma. They are comparable with autoliths, since they represent fragmented solid to semi-solid (crystal mush) material from the chamber.

The cognate fragments and the preserved magma mixing textures imply the existence of a relatively shallow magma chamber prior to the eruption. They also suggest that the magma mixing episodes happened shortly before emplacement of the diatremes, dykes and lavas. In fact, this may well be considered as a plausible triggering mechanism for magma disruption and diatreme formation.

Chemical evidence support the conclusion that magma mixing played an important role in the evolution of the studied rocks. This is consistent with the textural evidence for the existence of an unexposed magma chamber.

Volumetrically the coherent rocks are much more important in Santo Antônio da Barra, than in Águas Emendadas, where pyroclastic rocks are the most prominent. Features of magma mixing are much more persistent in the Águas Emendadas region than in Santo Antônio da Barra. This striking difference may be related to the way or degree that magma mixing happened in the two regions. For instance, in Santo Antônio da Barra the magma chamber could be bigger, hotter or deeper, mixing homogeneously in a way that magma mixing was not as effective as to cause rapid volatile exsolution and magma fragmentation, or simply did not happened. On the other hand, violent extrusion of magma occurred in Águas Emendadas, where magma mixing could have destabilised the magma body, resulting in fragmented magma ascent, forming pyroclastic material and culminating in diatreme generation.

\section{ACKNOWLEDGEMENTS}

The authors wish to thank CNPq - Brazilian Council for Research and Development for a Ph.D. grant (TCJB) research grants (JCG and JAB) and an undergraduate research grant (ERSB). University of Durham and Universidade de Brasília are gratefully acknowledged for granting access to analytical facilities.

\section{REFERENCES}

Danni, J.C.M., Silva, A.J.G.C., Cerqueira, M.R., 1990. Petrography and geochemistry of cretaceous alkaline rocks of the Serra do Caiapó, southwestern Goiás. Proc. 36 Congresso Brasileiro de Geologia, Natal, Brazil, pp. 1872-1882. (in portuguese)

Foley, S.F., Venturelli, G., Green, D.H., Toscani, L., 1987. The Ultrapotassic Rocks: Characteristics, Classification, and Constrains of Petrogenetic models. Earth-Sci. Rev. 24:81-134.

Gaspar, J.C., Danni, J.C.M.,1981. Petrographic and volcanological aspects of the Santo Antônio da Barra Alkaline-Carbonatite Province, southwest Goiás. Revista Brasileira de Geociências, 11:74-83. (in portuguese)

Haskin, L.A., Haskin, M.A., Frey, F.A., Wildman, T.R., 1968. Relative and absolute terrestrial abundances of the rare earths. In: Ahrens, L.H. (Ed.), Origin and distribution of the elements, vol. 1. Pergamon, Oxford, pp. 889-911.

Hasui, Y., Cartner-Dyer, R.E., Iwanuch, W., 1971. Geochronology of the Santo Antônio da Barraalkaline 
rocks. Proc. 25 Congresso Brasileiro de Geologia, São Paulo, pp. 253-258. (in portuguese)

Junqueira-Brod, T.C., 1998. Cretaceous Alkaline Igneous Rocks from the Águas Emendadas Region, Goiás, Central Brazil. M.Sc. Thesis, University of Durham, UK.

Junqueira-Brod, T.C., Roig, H.L., Gaspar, J.C., Brod, J.A., Meneses, P.R., 2002. The Goiás Alkaline Province and the extension of its kamafugitic volcanism. Revista Brasileira de Geociências, 32, in press. (in portuguese)

Lacerda Filho, J.V., Rezende, A., Silva, A., 2000. Brazilian Basic Geological Mapping Programme. Geology and Mineral Resources of Goiás and the Federal District. Text and 1:50000-scale map. CPRM/METAGO/UnB, Brasília, Brazil.(in portuguese)

Nakamura, N., 1974. Determination of REE, Ba, Fe, Mg, Na and $\mathrm{K}$ in carbonaceous and ordinary chondrites. Geochim. Cosmochim. Acta 38:757-775.

Sahama, Th.G., 1974. Potassium-rich alkaline rocks. In: H. Sorensen (Ed.), The Alkaline Rocks. Wiley, New York, NY, pp 2-5, 97-109.

Sgarbi, P.B.A., Clayton, R.N., Toshiko, K.M., Gaspar, J.C., 1998. Oxygen isotope thermometry of Brazilian potassic volcanic rocks of kamafugitic affinities. Chem. Geol. 146:115-126.

Tompkins, L.A., 1987. Exploration for kimberlites in southwest Goiás region, Brazil: Mineral chemistry of stream sediment samples. J. Geochem. Explor. 27:128.

Woolley, A.R., Bergman, S.C., Edgar, A.D., Le Bas, M.J., Mitchell, R.H., Rock, N.M.S., Scott Smith, B.H., 1996. Classification of lamprophyres, lamproites, kimberlites, and the kalsilitic, melilitic, and leucitic rocks. Can. Mineral. 34:175-186.

Contact: TC Junqueira-Brod, Instituto de Geociências,

Universidade de Brasília, Brasília-DF, Brazil 70910-900,

tcjbrod@unb.br 